\title{
Corrosion of Roofing Sheets in a Simulated Environment
}

\author{
J.E.O. Ovri \\ Department of Materials and Metallurgical Engineering, \\ Federal University of Technology, Owerri, Nigeria \\ *Corresponding Author: J.E.O. Ovri, Department of Materials and Metallurgical Engineering, Federal \\ University of Technology, Owerri, Nigeria

\begin{abstract}
An acid rain condition was simulated by mixing $0.5 \mathrm{MHCl}, 0.5 \mathrm{MH}_{2} \mathrm{SO}_{4}$ and $0.5 \mathrm{MHNO}$. Selected roofing sheets (galvanized steel, aluminum/zinc alloy(Cameroon zinc) and Aluminum alloy (Alumaco) were exposed to the simulated environment and to the various acids. The corrosion in these environments were monitored for 28-day at an interval of 7-day using the weight loss method. The results obtained indicated that the corrosion rates for the roofing sheets for the various environments were: galvanized steel (5.32 19.71mpy (HCL),9.85-39.77 mpy $\left(\mathrm{H}_{2} \mathrm{SO}_{4}\right)$, 9.03-13.69 mpy $\left(\mathrm{HNO}_{3}\right)$, and 5.72-22.33 mpy (simulated environment), aluminum/zinc alloy,6.42-17.32 mpy $(\mathrm{HCL})$, 4.04-7.71 mpy $\left(\mathrm{H}_{2} \mathrm{SO}_{4}\right)$, 7.82-7.94 mpy $\left(\mathrm{HNO}_{3}\right)$, 3.10-3.14 mpy (simulated environment) and aluminum alloy (Alumaco ),4.57-15.49 (HCL), 2.57-3.46 mpy $\left(\mathrm{H}_{2} \mathrm{SO}_{4}\right), 4.79-6.35 m p y\left(\mathrm{HNO}_{3}\right)$ and 2.32-3.45mpy (simulated environment). The galvanized steel corroded more in the simulated environment (5.72-22.33 mpy), closely followed by the aluminum/ zinc alloy which had 3.10-3.14 mpy. The aluminum alloy had the least corrosion 2.32-3.45 mpy. It could be concluded that the aluminum alloy appeared to be a more attractive material for roofing in the simulated environment which replicates an acid rain condition.
\end{abstract}

Keywords: Acid rain, Simulated, Aluminum/Zinc alloy, Weight loss, Environment.

\section{INTRODUCTION}

Acid rain occurs when sulphur dioxide $\left(\mathrm{SO}_{2}\right)$ and nitrogen oxide $\left(\mathrm{NO}_{2}\right)$ react with oxygen in the air in the presence of water to form carbonic acid $\left(\mathrm{H}_{2} \mathrm{CO}_{3}\right)$ and nitrous oxide $\left(\mathrm{HNO}_{2}{ }^{-}\right)$. These fall on the surface of roofing materials and have devastating effects. The $\mathrm{pH}$ of these acids are generally lower than 5. The acid rain has in addition to the nitrous and the sulphurous oxides contains heavy metals, carbon monoxide, and photochemical oxidants. A synergistic damaging effects is produced by the reactions between these materials. Recall that an electrolyte is required for corrosion to occur, roofing sheets therefore, corrode under acidic water and or condensation that can't run off or become trapped. The greenhouse gases (methane, $\mathrm{C} 0, \mathrm{CO}_{2}, \mathrm{SO}_{3}, \mathrm{SO}_{2}$, and $\mathrm{NO}_{2}$ ) are the main pollutants with respect (Ovri and Iroh, 2013) to corrosion. The reaction between the pollutants and roofing sheets is complex and involved variables such as the pollutants's concentration and the climatic conditions and the exposed surface of the roofing sheet. Once the pollutant gets to the surface of the roofing sheet, the interaction will depend on the amount, duration of exposure, reactivity of the various materials (gases, moistures etc).

Acid rain is a major environmental problem in the Niger Delta of Nigeria. This is more serious during the raining session when the humidity is high and with the presence of the greenhouse gases, there is an increase in the corrosion of roof sheets. The effects of acid rain on corrugated iron sheet has been documented by (Barton, 1997, Graedel and Schwartz, 1997 and Haynic,1982). The effect of gas flaming on roofing sheets in a gaseous and non-gaseous flaring areas has been documented by ( Ovri and Iroh, 2013).

This investigation is aimed at providing a data base for roofing sheets commonly used in the Niger Delta areas of Nigeria. These areas are often plagued with acid rain. The roofing sheets investigated were, (i) galvanized steel, (ii) Aluminum roofing sheet (Alumaco) and Aluminum / zinc alloy roofing sheet ( Cameroon roofing sheet). The relative corrosion resistance of these roofing sheets in the 
various environments were evaluated and recommendations made on the most suitable sheets for these environments. The results of this investigation will be invaluable to engineers, designers, Architects and builders.

\section{ExPerimental Procedures}

\subsection{Materials and Methods}

\subsubsection{Materials}

\subsubsection{Roofing Sheets}

The roofing sheets were obtained from the open building materials market in Owerri, Imo State.

These were: (i) galvanized steel sheets,

(ii) Aluminum/ Zinc alloy (Cameroon roofing sheets), and

(iii) Aluminum roofing sheet (Alumaco).They were all in the form of corrugated sheets.

\subsubsection{Coupons Preparation}

From each roofing sheets 60 coupons of dimensions $40 \mathrm{~mm} \times 30 \mathrm{mmx} 0.25 \mathrm{~mm}$ were cut using a hacked saw. A hole of $3 \mathrm{~mm}$ diameter was drilled on each coupon for suspension in the various environments. The chemical composition of the roofing sheets are given in Table 1.

Table1. Chemical Composition of the Roofing Sheets

\begin{tabular}{|c|c|c|c|c|c|c|c|c|c|c|c|c|c|c|c|c|c|}
\hline Roofing sheets & \multicolumn{17}{|c|}{ Elements (Wt\%) } \\
\hline & $\mathrm{Fe}$ & $\mathrm{C}$ & $\mathrm{Si}$ & $\mathrm{Mn}$ & $\mathrm{P}$ & Mo & $\mathrm{Cu}$ & $\mathrm{Al}$ & $\mathrm{Ti}$ & $\mathrm{V}$ & $\mathrm{Sn} / \mathrm{Zn}$ & $\mathrm{S} / \mathrm{Ca}$ & $\mathrm{Cr}$ & $\mathrm{Ni}$ & Co & $\mathrm{Nb}$ & $\mathrm{W}$ \\
\hline $\begin{array}{l}\text { Galvanized } \\
\text { Steel }\end{array}$ & 99.06 & 0.073 & 0.063 & 0.153 & 0.031 & - & 0.03 & 0.078 & 0.002 & 0.021 & 0.047 & 0.030 & 0.046 & 0.009 & 0.013 & 0.117 & 0.119 \\
\hline \begin{tabular}{|c|} 
Aluminum/Zinc \\
Alloy \\
\end{tabular} & 0.317 & - & 0.064 & 0.020 & - & - & 0.22 & 99.14 & 0.25 & 0.012 & $\begin{array}{c}0.002 \\
(\mathrm{Zn})\end{array}$ & - & - & - & - & - & - \\
\hline $\begin{array}{l}\text { Aluminum } \\
\text { Alloy }\end{array}$ & 0.50 & - & 0.12 & 0.23 & - & - & 0.07 & 96.43 & 0.02 & 0.015 & \begin{tabular}{|l|}
0.06 \\
$(\mathrm{Zn})$ \\
\end{tabular} & $\begin{array}{c}0.006 \\
(\mathrm{Ca})\end{array}$ & 0.02 & 0.34 & - & - & - \\
\hline
\end{tabular}

\subsubsection{Environments}

Four environments were used during the study. These were:

(i) $\quad 0.5 \mathrm{MH}_{2} \mathrm{SO}_{4}$ (Tetra-sulphate(iv)acid) to provide the sulphate ions.

(ii) $0.5 \mathrm{MHCL}$ (Hydrochloric acid) to provide the chloride ions.

(iii) $\quad 0.5 \mathrm{MHNO}_{3}$ (Tri-oxonitrate(v) acid) to provide the nitrate ions.

(iv) Mixture of $0.5 \mathrm{MH}_{2} \mathrm{SO}_{4}, 0.5 \mathrm{MHCL}$ and $0.5 \mathrm{MHNO}_{3}$ to provide the simulated environment.

These environments were labeled alphabetically as A,B,C and D as shown below:

\begin{tabular}{|c|c|}
\hline Environment & Designation \\
\hline $0.5 \mathrm{MH}_{2} \mathrm{SO}_{4}$ & A \\
\hline $0.5 \mathrm{MHCL}$ & B \\
\hline $0.5 \mathrm{MHNO}_{3}$ & $\mathrm{C}$ \\
\hline Simulated & D \\
\hline
\end{tabular}

\subsubsection{Methodology}

\subsubsection{Weight loss Measurement}

All linear measurements were made using a steel rule whilst all thicknesses were made using a dial Vernier caliper. The initial and final weights $\left(\mathrm{W}_{1}\right.$ and $\left.\mathrm{W}_{2}\right)$ were obtained using an Analytical digital balance.

\subsubsection{Corrosion Rates Measurement}

The corrosion rates measurement of the roofing sheets in the various environments were carried out according to ( Ovri and Ofeke, 1998) using the relation: 
Corrosion Rate $(\mathrm{mpy})=\underline{534 \mathrm{~W}}$

\section{DAT}

Where $\mathrm{W}$ is the weight loss in $\mathrm{mg}, \mathrm{D}$ is the density of the material $\mathrm{Mg} / \mathrm{m}^{3}$

A is the total surface area of material $\left(\mathrm{m}^{2}\right), \mathrm{T}$ is the exposure time in days and mpy is millimeter per year.

\subsubsection{Physical Examination of the Coupons}

The roofing sheets coupons,s surface were visually examined before and after immersion in the various environments with a view of identifying (Ovri, 1998):

(i) The type of substances clinging to the surface of the specimens,

(ii) The type of corrosion occurring, and

(iii) Any changes in the colour of the specimens and the corrosion products.

\section{EXPERIMENTS RESULTS AND DISCUSSION}

\subsection{Weight Loss of Corrosion Coupons}

The weight loss of the corrosion coupons as a function of exposure time in the various environments are given in Table 2 and displayed in Figure 1.

Table2: Weight Loss as Function of Exposure Time for the Roofing Sheets in the Various Environments.

\begin{tabular}{|c|c|c|c|c|c|}
\hline Material & Environment & \multicolumn{4}{|c|}{ Weight loss (mg) } \\
\hline & & 7 -day & 14 -day & 21 -day & 28 -day \\
\hline GalvanizedSteel & A & - & - & - & - \\
\hline & B & 661 & 1047 & 850 & 714 \\
\hline & C & 459 & 517 & 536 & 212 \\
\hline Aluminum/ Zinc Alloy & D & 749 & 1081 & 969 & 767 \\
\hline & A & 77 & 174 & 441 & 348 \\
\hline & B & 330 & 389 & 407 & 489 \\
\hline & C & 149 & 303 & 279 & 605 \\
\hline Aluminum & D & 60 & 121 & 178 & 239 \\
\hline Alloy & A & 51 & 124 & 363 & 274 \\
\hline & B & 307 & 278 & 379 & 362 \\
\hline
\end{tabular}

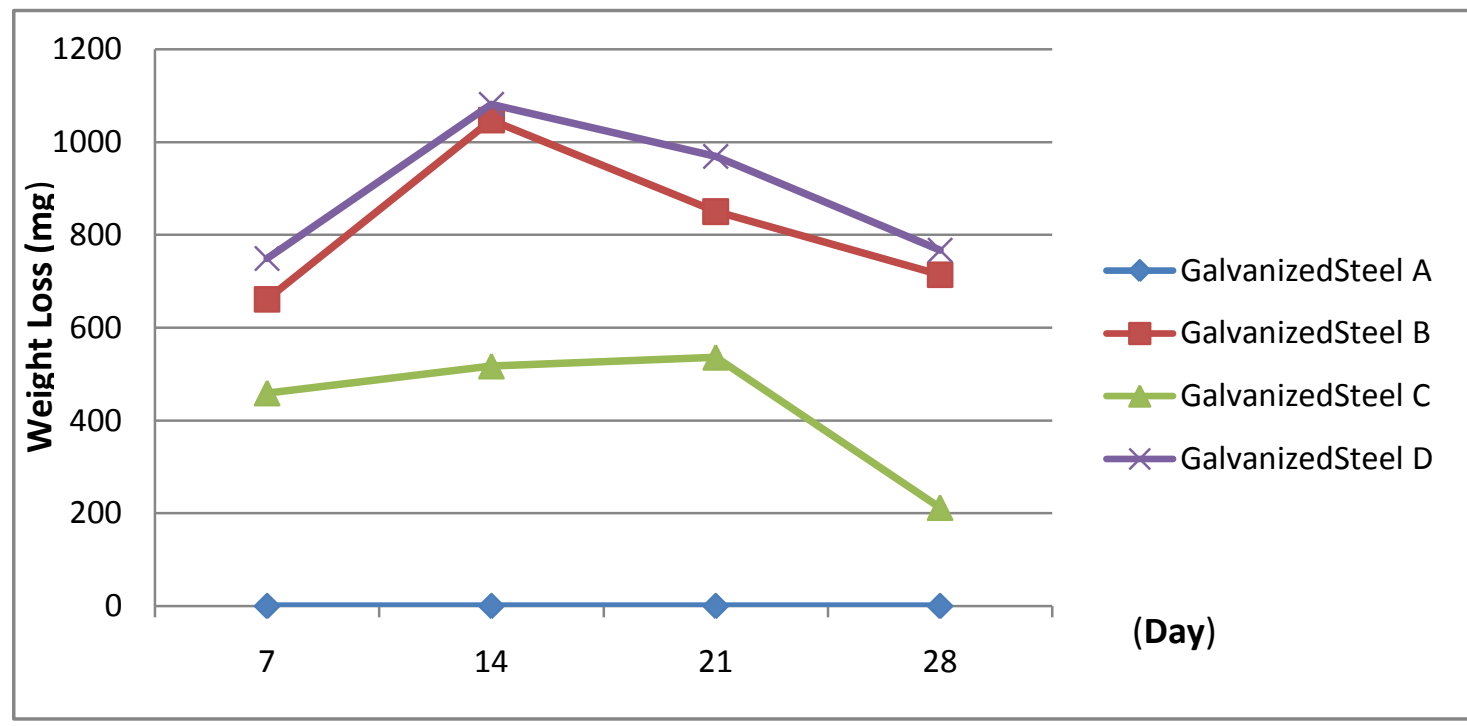

(a) 

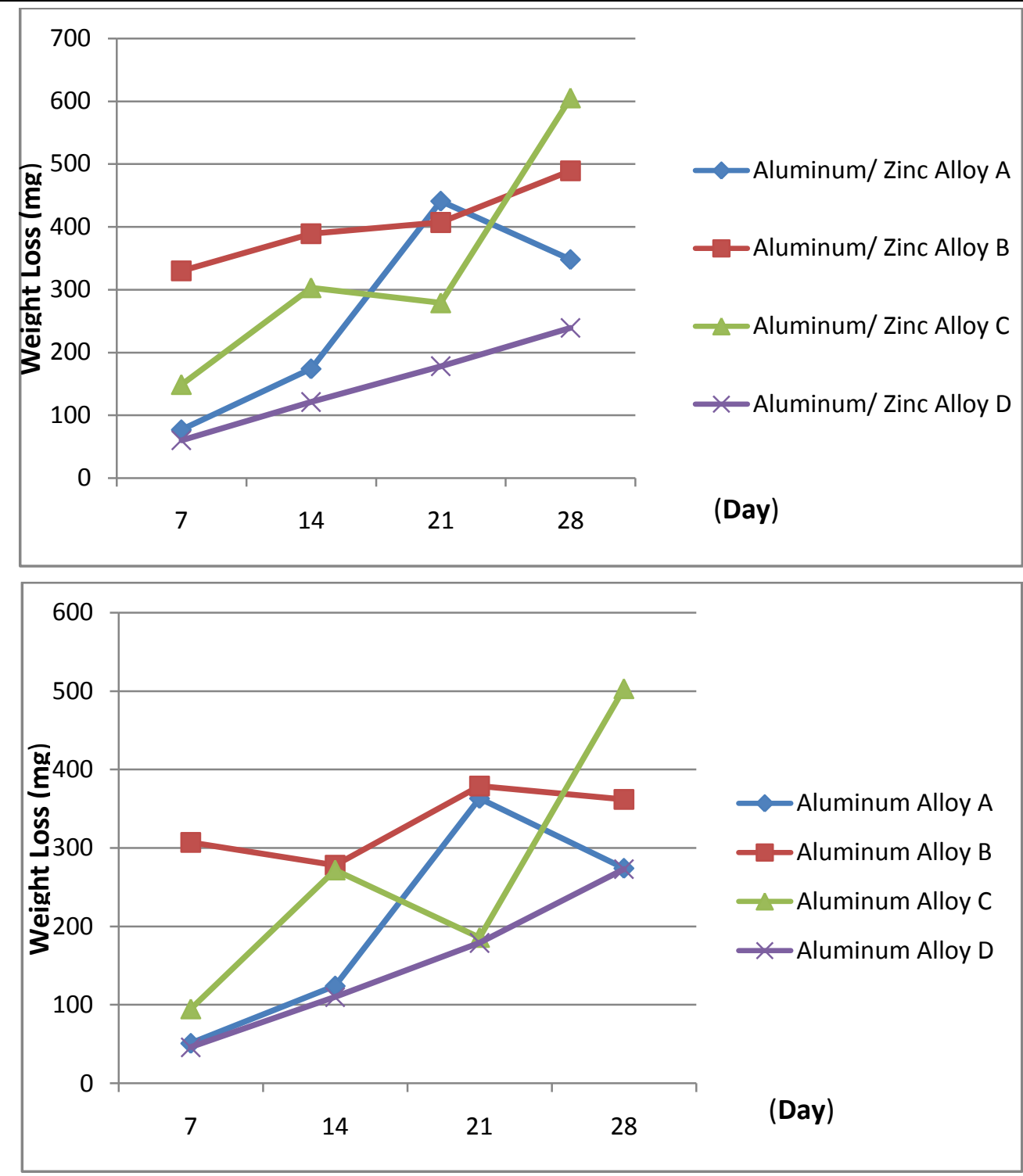

(b)

Fig1. A plot of Weight Loss as a Function of Environment: (a) Galvanized Steel, (b) Aluminum/Zinc Alloy and (c) Aluminum Alloy.

From the Table and the plots, the weight loss for galvanized steel in $\mathrm{H}_{2} \mathrm{SO}_{4}$ (Environment $\mathrm{A}$ ) is not reported due to some observed inconsistencies. However, for the Aluminum/Zinc alloy (Cameroon zinc), it is observed that the weight loss increased with exposure time but decreased at the 28th day. The same observation also occurred with the Aluminum alloy, with a decreased in the weight loss at the 28th day .This behaviour is perhaps due to the high aluminum contents in these materials.

The weight loss in the simulated environment showed a linear increase with time for the galvanized steel, the aluminum/zinc alloy and the aluminum alloy. The synergistic effect of the combined acids is shown here. This environment is a replicate of the service condition of the roofing sheets. The result is in qualitative agreement with (Ovri and Iroh, 2013 and Abdulkarim et al, 2009).

\subsection{Corrosion Rates in the Various Environments}

The corrosion rates for the roofing sheets are given in Table 3 and displayed in Figure 2.

Table3. Corrosion Rates of the Roofing Sheet as a Function of Environment and Exposure Time (days).

\begin{tabular}{|c|c|c|c|c|c|}
\hline Materials & Environment & \multicolumn{4}{|c|}{ Corrosion Rates (mpy) } \\
\hline & & 7 -day & 14 -day & 21 -day & 28 -day \\
\hline GalvanizedSteel & A & 39.77 & 19.44 & 13.35 & 9.85 \\
\hline & B & 19.71 & 15.61 & 8.45 & 5.32 \\
\hline & C & 13.69 & 16.74 & 5.33 & 9.03 \\
\hline Aluminum/Zinc Alloy & D & 22.33 & 16.11 & 9.63 & 5.72 \\
\hline
\end{tabular}


Corrosion of Roofing Sheets in a Simulated Environment

\begin{tabular}{|c|c|c|c|c|c|}
\hline & B & 17.32 & 10.21 & 7.12 & 6.42 \\
\hline & C & 7.82 & 7.95 & 4.88 & 7.94 \\
\hline & D & 3.10 & 3.18 & 3.11 & 3.14 \\
\hline AluminumAlloy & A & 2.57 & 3.13 & 6.11 & 3.46 \\
\hline & B & 15.49 & 7.01 & 4.78 & 4.57 \\
\hline & C & 4.79 & 6.86 & 3.13 & 6.35 \\
\hline & D & 2.32 & 2.78 & 2.98 & 3.45 \\
\hline
\end{tabular}

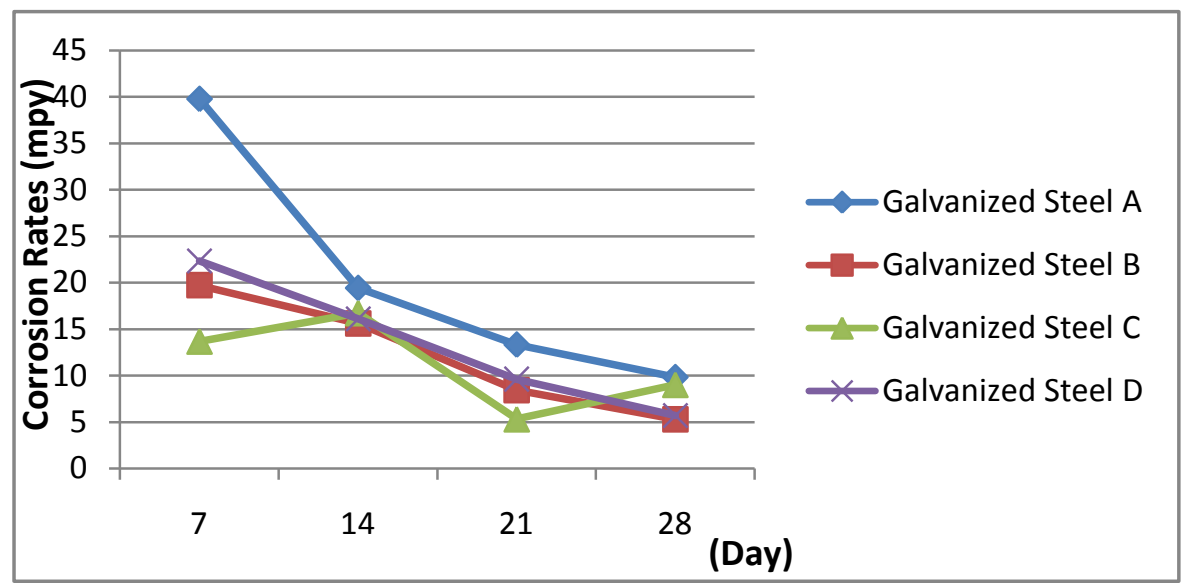

(a)

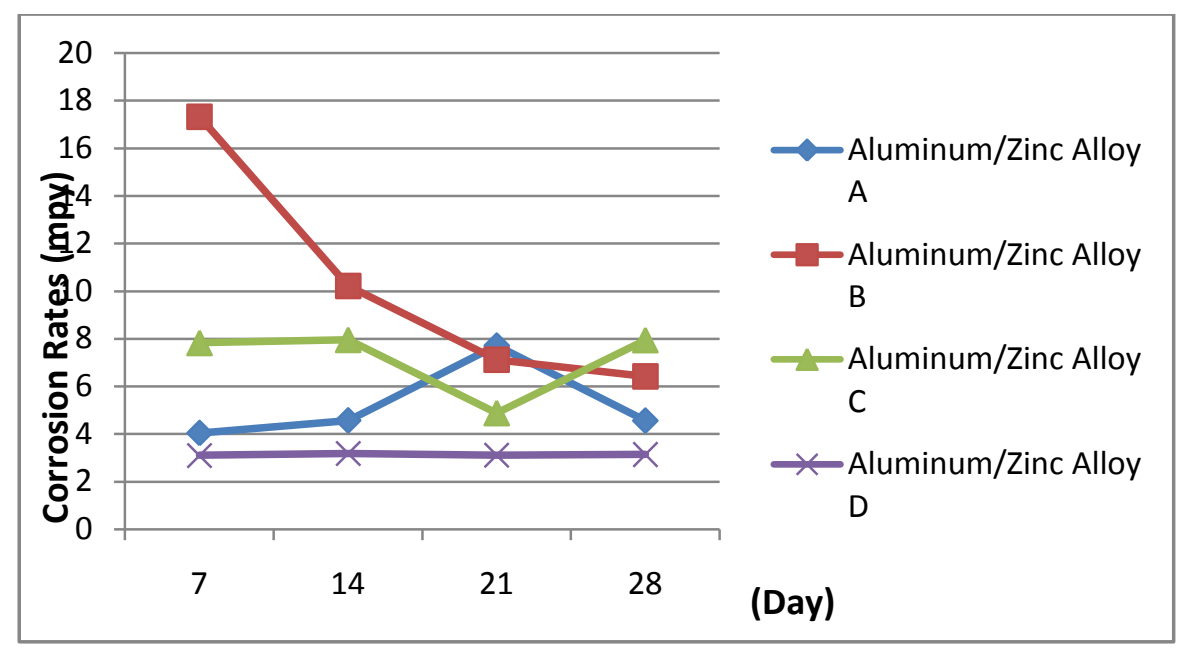

(b)

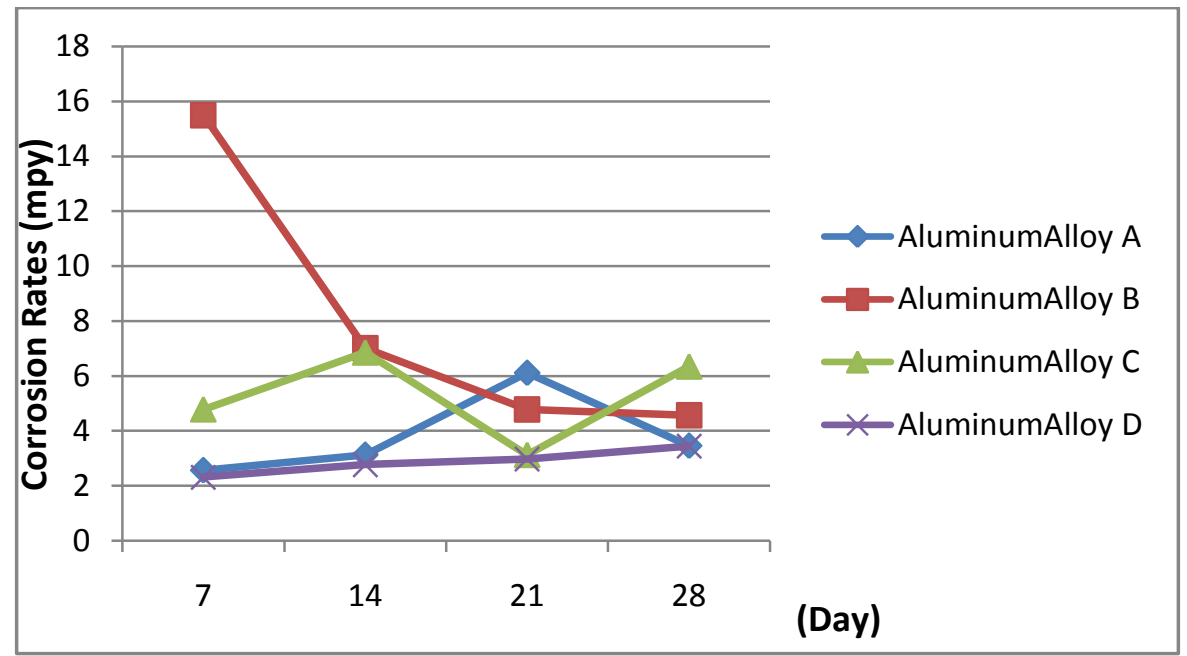

(c)

Fig2. A Plot of Corrosion Rates as a Function of Environment: (a) Galvanized Steel, (b) Aluminum/ Zinc Alloy and (c) Aluminum Alloy.

\subsubsection{5 $\mathrm{MH}_{2} \mathrm{SO}_{4}(\mathrm{~A})$}

\subsubsection{Galvanized Steel}

The galvanized steel has the highest corrosion rate in the first week and this decreased in the second week and third week respectively, this is likely due to the result of passivation (Ovri, 1998). An 
increase in corrosion was observed in the fourth week ( $28^{\text {th }}$ day) and this may be as a result of depassivation, when the protective corrosion oxide is broken, that point becomes anodic to the entire structure with attendant increase in corrosion (Ovri, 1998, Ovri, 1999).

\subsubsection{Aluminum/Zinc Alloy (A)}

The aluminum/ Zinc alloy showed an initial slow corrosion rate, this increased steadily during the second and the third weeks but a drastic decrease in the corrosion rate was observed in the fourth week. This behaviour is perhaps due to the protective action of the corrosion oxide. This observation is in agreement with previous report (Ovri, 1998, Ovri, 1999).

\subsubsection{Aluminum Alloy (A)}

The aluminum alloy had the lowest initial corrosion in the first week and increased slightly during the second week and reached the highest during the third week and reduced drastically during the fourth week. This reaction is as a result of passivation (Ovri,1998, Ovri,1999). It is observed that the galvanized steel has the highest corrosion, followed by the aluminum/ zinc alloy and the aluminum alloy. It could therefore be concluded that the aluminum alloy has a better corrosion resistance in this environment.

\subsection{MHCL (B)}

\subsubsection{Galvanized Steel}

The galvanized steel has the highest corrosion rate during the first week of exposure in this environment. This decreased with time till the fourth week when the least corrosion rate was observed. This corrosion reduction is due to the formation of the protective oxide formed on the structure, so long as this oxide is protective.

\subsubsection{Aluminum/Zinc Alloy}

The initial corrosion is slightly lower than that of the galvanized steel. This decrease with time (second and third week) but slightly increase during the fourth week and this is due to depassivation of the protective corrosion oxide (Ovrl, 1999).

\subsubsection{Aluminum Alloy(B)}

The initial corrosion rate is also lower and steadily decreased with time. This decreased in corrosion is due in part to the protective corrosion product formed on the structure. It could be inferred that the aluminum alloy provides a better corrosion resistance in this environment, followed by the aluminum/ zinc alloy.

\subsection{MHNO3 (C)}

\subsubsection{Galvanized Steel}

The galvanized steel has a higher initial corrosion and increased during the second week and decreased during the third week due in part to passivation. The corrosion rate increased during the fourth week.

\subsubsection{Aluminium/Zinc Alloy (C)}

The corrosion rates increased during the first and second weeks but decreased in the second week due partly to passivation and increased in the $28^{\text {th }}$ day. This increase is probably due to the destruction of the protective oxide on the surface of the structure. This is in qualitative agreement with previous works (Ovri, 1998,Ovri,1999).

\subsubsection{Aluminum Alloy $(C)$}

The corrosion rates are generally lower than the aluminum/zinc and galvanized steel. The corrosion rate increased during the second week and decreased dramatically during the third week and increased during the fourth week. The aluminum alloy appeared to provide good corrosion resistance in this environment.

\subsection{Simulated Environment}

This environment provides a near condition in which the roofing sheets are used. The synergistic actions of the acids are shown here. 


\subsubsection{Galvanized Steel (D)}

The corrosion of the galvanized steel is generally higher, decreasing with exposure times due perhaps to passivation effects. The galvanized steel is similar to the standard steel grade 1020 with a carbon content of about $0.0734 \%$. This carbon content will give a purely ferritic structure with little pearlite. Ferrite is a very corrosive phase, and its present will act as an anode to the entire structure. This perhaps explained the high corrosion of the steel in this environment.

\subsubsection{Aluminum/ Zinc Alloy (D)}

The corrosion rates of the aluminum/ zinc alloy is essentially constant in this environment (the lowest being 3.10 and highest $3.18 \mathrm{mpy}$ ). This material has a high aluminum content of approximately 99.14\% Al. With this high aluminum content coupled with the zinc coating, it is expected that this material would possess good corrosion resistance. Other materials present like silicon $(0.0644 \%)$, manganese, chromium, titanium will improve corrosion resistance.

\subsubsection{Aluminum Alloy (D)}

The corrosion rates are given in Table 3 and displayed in Figure 2, shows that the corrosion rates is generally lower and increased marginally with time. A slightly higher corrosion rate was obtained in the fourth week, which is likely due to depassivation (as a result of the breakdown of the protective corrosion oxide). The aluminum content of this material is lower than that of the aluminum/ zinc alloy (96.43\%). The higher corrosion resistance of this material is perhaps due to the alloying elements present in this material which are generally higher than those of the aluminum/zinc alloy. The galvanized steel has higher corrosion, followed by the aluminum/zinc alloy and the aluminum alloy has the least corrosion in this medium. It would therefore be concluded that the aluminum alloy is the most suitable material for this environment.

\section{Physical Examination Results}

The physical examination results are given in Table 4 and all the observed features for each material and environments are given.

Table 4. Physical Examination Results for the Roofing Sheets

\begin{tabular}{|c|c|c|c|}
\hline Environment & Galvanized Steel & Aluminum/Zinc & Aluminum Alloy \\
\hline $\mathrm{H}_{2} \mathrm{SO}_{4}$ (A) & Totally dissolved & Localized Pitting & Very dull Surface \\
\hline $\mathrm{HCL}$ (B) & $\begin{array}{c}\text { Weight loss with thick } \\
\text { brownish deposits }\end{array}$ & $\begin{array}{c}\text { Roughening of the surface, } \\
\text { Grey deposits }\end{array}$ & $\begin{array}{c}\text { More roughing of the } \\
\text { surface with grey deposits }\end{array}$ \\
\hline $\mathrm{HNO}_{3}$ ( C) & Totally Dissolved & Increased localized pitting & Peeling of coating \\
\hline $\mathrm{Simulated}^{\text {To })}$ & $\begin{array}{c}\text { Total wear of the surface, } \\
\text { heavy rust (uniform } \\
\text { corrosion) }\end{array}$ & $\begin{array}{c}\text { Very dull surface with grey } \\
\text { deposits }\end{array}$ & $\begin{array}{c}\text { Dull surface, increased } \\
\text { roughing almost looking like } \\
\text { pits. }\end{array}$ \\
\hline
\end{tabular}

\section{CONCLUSIONS}

The following conclusions could be drawn from this investigation:

(1) Galvanized Steel, Aluminum/Zinc and Aluminum alloys had higher corrosion rates in the $\mathrm{H}_{2} \mathrm{SO}_{4}$ evironment than in the $\mathrm{HCL}, \mathrm{HNO}_{3}$ and the simulated environments.

(2) Galvanized Steel corroded more in the simulated environment whilst the Aluminum alloy had the least corrosion followed by the Aluminum/Zinc alloy. The Aluminum alloy is preferred as the most suitable material for these environments.

(3)The Aluminum alloy appeared to be more corrosion resistant in all the environments investigated and it is therefore recommended for use in these environments.

(4)The Synergistic effects of mixing acids improved the corrosion resistance for the Aluminum/Zinc and the Aluminum alloys whilst the Galvanized steel corrosion rates were increased.

(5)The physical examination of the various roofing sheets showed that corrosion were more severe in galvanized steel in the $\mathrm{H}_{2} \mathrm{SO}_{4}$ and $\mathrm{HNO}_{3}$ and less for the simulated environment. localized pitting were observed for the Aluminum/Zinc and Aluminum alloys for the acids whilst a dull and grey deposits where found for the simulated environment. 


\section{ACKNOWLEDGEMENT}

The author wish to acknowledge the assistance of Miss Chioma Okechukwu for providing some of the experimental data.

\section{REFERENCES}

[1] Abdulkarim, B.I, Yusuf, A. A. and Kamoru, A. S., (2004): "Corrosion Resistance of Commercial Roofing Sheets to Acid Rain Water in Eleme, Rivers State Nigeria” Int. Journ. Chem. Techn. Res., Vol. 1, No. 4, PP 802 - 806.

[2] ASTM International, (2009): "Standard Practice for Laboratory Immersion of Corrosion Testing of Metals" American Society for Testing and Materials, Philadelphia.

[3] Barton, K., (1997): Protection Against Atmospheric Corrosion: Theories and Methods, Vol. 3, John Wiley and Sons, London.

[4] Branko, N. P., (2015): Corrosion Engineering Principles and Solved Problems, Elsevier, B.V.

[5] Bushman, J. B., (2000): Corrosion and Cathodic Protection, Bushman and Associates Inc, Medina Ohio, U.S.A, P89-150.

[6] Chukwuocha, E. and Owate, I. O. (2002): "Corrosion Resistance of Metals" Journ. Appl. Sci. and Environ. Mag., University of PortHarCourt, Vol. 6, No. 2, PP 33-35.

[7] Ehterain, A.N. and Aisha, H. A., (2008): "Corrosion Behaviour of Mild Steel in Hydrochloric Acid Solution”, Int. Journ. Electochem. Sci., 3 ,PP 806-818.

[8] Einar, B., (2004): Corrosion and Protection, Springer Vertag, London Limited, PP 89-237.

[9] Heinler, B. and Vannerberg, N., (2003) "A Microscopic Study of Steel Surfaces Exposed to a Humid Sulphur Dioxide Containing Atmosphere” Corrosion Science, P579.

[10] Micafferty, E., (2005): Corrosion Science, 47, P3202.

[11] Nwoko, V. O. and Umoru, L. E., (1998): “Corrosion of Mild Steel in Some Environments" Journ. Corr. Sci. Vol.1, PP 61-65.

[12] Oforka, N.C.,Wogu, C. I. and Abiola, O. K., (2004): “ Inhibition of Acid Corrosion of Galvanized Steel by I - phenyl- 3 -Methlpyrazol - 5 -one”, Journ. Corr. Sci. Tech. 3, PP 101 -103.

[13] Osarolube, E., Owate, I. O. and Oforka, N. C., (2004): "The Influence of Acidic Concentration on Corrosion of Copper and Zinc" Journ. Corr. Sci. Techn. 1.1, PP 66-69.

[14] Ovri, J. E. O., (1998): "Corrosion of Mild Steel in Concrete in Acidic and Fresh Water Environments" Journ. Corr. Sci. Vol. PP 1-9.

[15] Ovri, J. E. O., (1998): “Corrosion Resistance of MgMnZn Ferrite in Hostile Environments” -libid-,PP 6571

[16] Ovri, J. E. O. and Iroh, M., (2013): "Corrosion Effect of Gas Flaring on Roofing Sheets in Imo State, Nigeria” Inter. Journ. Eng.Sci. (IJES), Vol. 2 Issue 1, PP 339 -346.

[17] Ovri, J.E.O. and Ofeke,B.G.,(1998): "The Corrosion Behaviour of Mild Steel in a Marine Environment" J.Sci. Engr. Tech. 5 (2), June, pp1117-1129.

Citation: J.E.O. Ovri (2017). Corrosion of Roofing Sheets in a Simulated Environment, International Journal of Mining Science (IJMS), 3(2), pp.1-8. DOI: http://dx.doi.org/10.20431/2454-9460.0302001

Copyright: (C) 2017 J.E.O. Ovri. This is an open-access article distributed under the terms of the Creative Commons Attribution License, which permits unrestricted use, distribution, and reproduction in any medium, provided the original author and source are credited 